\title{
ЗАШТИТА ОД ЛОКАЛНЕ ЕРОЗИЈЕ КОРИТА РЕКЕ ОКО МОСТОВСКИХ СТУБОВА И ОБАЛЕ
}

\section{PROTECTION AGAINST LOCAL EROSION OF THE RIVERBED AROUND THE BRIDGE PIERS AND THE EMBANKMENT}

\author{
Радован Туцић, Факултет техничких наука, Нови Сад
}

\begin{abstract}
Област - ГРАЂЕВИНАРСТВО
Кратак садржај -Рад се бави анализом како би се утврдило колико ће изградња новог моста утицати на промену хидрауличко-морфолошког режима реке Дунав на предметном потезу. Као и да се дају препоруке за евентуалне мере заштите у зони стубова моста (стабилизачија корита), уколико се овом анализом утврди да стабилност моста може бити угрожена, такође је предвиђена и изградња обалоутврде, на левој и десној обали Дунава.
\end{abstract}

Кључне речи: Локална ерозија мостовских стубова, израда обалоутврде, хидраулички прорачун

Abstract - The paper deals with the analysis in order to determine how much the construction of a new bridge will affect the change of hydraulic-morphological regime of the Danube on the given stretch. It also gives recommendations for possible protection measures in the area of bridge piers (stabilization of the riverbed). In case the analysis proves that the stability of the bridge may be endangered, the construction of a bank fortification on the left and right banks of the Danube is also planned.

Keywords: Local erosion of bridge piers, construction of embankment, hydraulic calculation

\section{1. УВОД}

Локална ерозија речног корита у периоду великих вода представља главни природни узрок рушења и оштећења мостова. Према статистичким подацима у свету као на пример у Америци, у периоду од 1996. до 2005. године десило се око 900 хаварија на мостовима, 58\% је настало услед локалне ерозије речног корита, док на пример у Енглеској у просеку на сваке 2.5 године деси се једна хаварија моста, при чему је поткопавање мостовских стубова и опораца главни узрок рушења моста. На Новом Зеланду најмање једно рушење моста у време поплаве дешава се у просеку сваке године. Слични подаци постоје и у другим земљама.

Предмет овог мастер рада је анализа хидрауличких и морфолошких карактеристика реке Дунав у зони новопројектованог моста са обилазницом око Новог Сада.

\section{НАПОМЕНА:}

Овај рад проистекао је из мастер рада чији ментор је био доц. др Слободан Колаковић.
Прорачуном се врши провера како би се утврдило колико ће изградња новог моста утицати на промену хидрауличко-морфолошког режима реке Дунав на предметном потезу и да се дају препоруке за евентуалне мере заштите у зони стубова моста (стабилизација корита), уколико се овом анализом утврди да стабилност моста може бити угрожена, такође радом је предвиђена и изградња обалоутврде, на левој и десној обали Дунава.

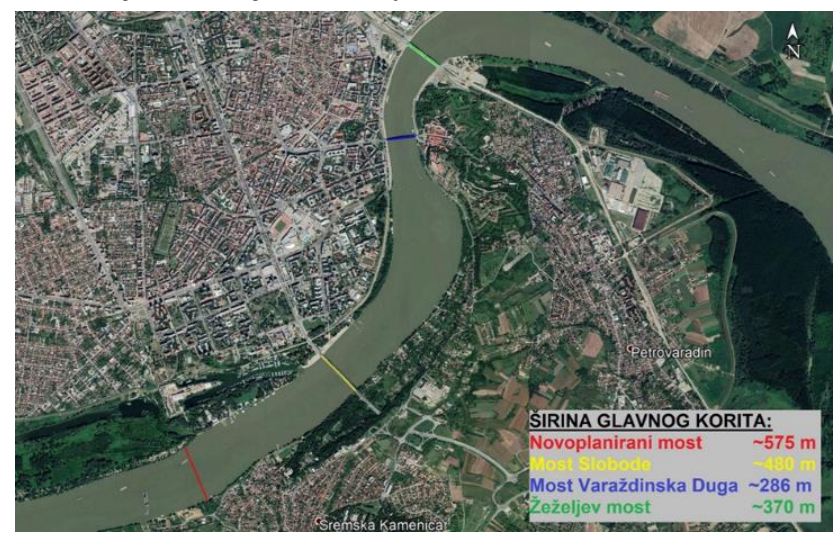

Слика 1. Локаџија планираног моста преко Дунава

\section{2. ЕРОЗИОНИ ПРОЦЕСИ И ОШТЕТЕЊА MOCTOBA}

Када су у питању мостови, у оквиру регулације река се разматрају три вида деформације речног корита:

- $\quad$ општа деформација

- $\quad$ локална ерозија услед мостовског сужења

- локална ерозија око мостовских стубова и опораца

До укупне деформације на локацији моста долази се суперпозицијом претходно наведених деформација.

Општа деформација корита се одвија на дугачким речним деоницама и манифестује се као регресивна ерозија или као засипање корита. Општа деформација се неутралише изградњом система стабилизационох прагова, на рекама мале и средње величине ово решење се нарочито препоручује узводно и нозводно од мостова.

Локална ерозија услед мостовских сужења настаје услед локалног повећања брзине у сужењу основног корита изградњом моста јер се смањује протицајни профил и представља уско грло за проток воде. 
Оваква ерозија је нарочито изражена код сложеног корита са инундацијама, где дугачке прилазне конструкције моста у периоду великих вода ометају (а понекад и потпуно заустављају) течење по инундацијама и усмеравају воду ка главном кориту.

Локална ерозија корита око мостовских стубова и опораца (обалних стубова) настаје услед повећане локалне брзине и тангенцијалног напона дуж чврсте контуре стуба или опорца, стварањем вртлжног система. За стабилност мостовских конструкција примарна је локална ерозија речног корита око стубова и опораца, па ће се у овом раду највећа пажња и посветити локалној ерозији у зони мостовских стубова.

\section{3. ФИЗИКА ЛОКАЛНЕ ЕРОЗИЈЕ ОКО МОСТОВСКИХ СТУБОВА}

Типична вртложна структута око мостовског стуба је приказана слици 2, поремећај који настаје око чврсте контуре стуба доводи до повећане локалне брзине и интезивнијнег покретања наноса на речном дну.

Да би се формирала ерозионе јаме у зони мостовског стуба потребно је да локални транспортни капацитет речног тока за одношење материјала са дна буде већи од дотока наноса са узводне деонице.

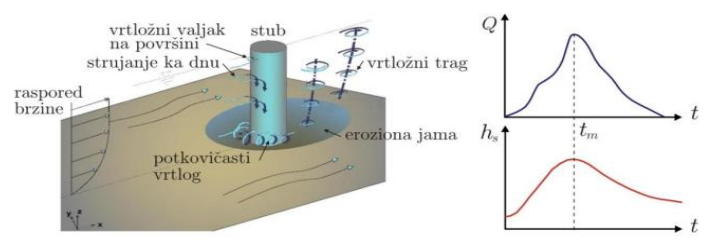

Слика 2. Еволуичија ерозионе јаме око стуба [1].

\section{4. ПРОЦЕНА ЛОКАЛНЕ ЕРОЗИЈЕ ОКО МОСТОВСКИХ СТУБОВА}

\section{1 Емпиријски приступ}

Према теоријским разматрањима у физичком процесу локалне ерозије стубова мостова утиче низ параметара: динамички коефицијент вискозности $\mu$, густина воде $\rho$, убрзање силе земљине теже $g$, средња брзина тока $v$, дубина тока $h$, пречник зрна наноса $d$, стандардна девијација гранулометријског састава $\sigma_{g}$, ширина ступа $b$, итд. Математички опис тако сложеног процеса уводи низ рестрикција, па су и расположиви обрасци за прорачуне прилагођени карактеристичним условима конструкције и водотока. Већина ових непознатих приказана је преко коефицијената у емпиријским формулама за израчунавање ерозије око мостовских стубова.

Најједноставније једначине за прорачун локалне ерозије око стубова су оне у којима је функционална зависност дефинисана преко једног релевантног параметра, нпр. ширине ступа $b$.

У свету постоји преко тридесет емпиријских образаца за процену локалне ерозије око мостовских стубова у овом случају ће се користити пет израза, а то су следећи:

- $\quad$ CSU једначина

- Richardson-ова једначина
- $\quad$ Froehlich-ова једначина

- Mississippi једначина

- Inglis-Poona једначина

У наведеним изразима фигуришу следеће величине: $h_{s}$ - терминална ерозиона дубина, $h_{1}$ - средња дубина воде у непоремећеном струјном пољу узводно од стуба, $b_{s}$ - ширина стуба (управно на правац тока), $\mathrm{Fr}_{1}$ $=V_{1} /\left(g \cdot h_{1}\right)^{1 / 2}-$ Фрудов број, $V_{1}-$ средња профилска брзина тока, $K_{1}-K_{4}$ - емпиријски коефицијенти, $d_{50}-$ средњи пречник наноса на дну, $g$ - гравитационо убрзање, наведени обрасци важе без обзира да ли је ерозија у чистој води или при опште покретном дну [1].

\section{CSU једначина:}

$\frac{h_{s}}{h_{1}}=2 \cdot K_{1} \cdot K_{2} \cdot K_{3} \cdot K_{4} \cdot\left(\frac{b_{s}}{h_{1}}\right)^{0.65} \cdot F r_{1}{ }^{0.43}$

Richardson-ова једначина:

$h_{s}=C_{1} \cdot F^{0.43} \cdot\left(\frac{b_{s}}{h_{1}}\right)^{0.65} \cdot h_{1}$

Froehlich-ова једначина:

$h_{s}=0.32 \cdot K_{1} \cdot\left(K_{2}\right)^{0.62} \cdot h_{1}^{0.47} \cdot F r^{0.22} \cdot d_{50}^{-0.09}+b_{s}$

Mississippi једначина:

$h_{s}=0.9 \cdot b_{s}^{0.6} \cdot h_{1}^{0.40}$

Inglis-Poona једначина:

$h_{s}=1.7 \cdot b_{s}^{0.22} \cdot v^{0.52} \cdot h_{1}^{0.52}-h_{1}$

Табела 1. Табелерни приказ добијених резултата дубине ерозионе јаме у зони стубова

\begin{tabular}{|l|l|l|l|l|}
\hline Стуб & $\Pi 1$ & $\Pi 2$ & $\Pi 3$ & $\Pi 4$ \\
\hline CSU (m) & 5.69 & 5.66 & 5.85 & 5.69 \\
\hline Richardson (m) & 5.69 & 5.66 & 5.85 & 5.69 \\
\hline Froehlich (m) & 6.94 & 6.91 & 7.09 & 6.94 \\
\hline Mississippi (m) & 6.15 & 6.05 & 6.67 & 6.14 \\
\hline Inglis-Poona (m) & 7.70 & 7.55 & 8.43 & 7.69 \\
\hline
\end{tabular}

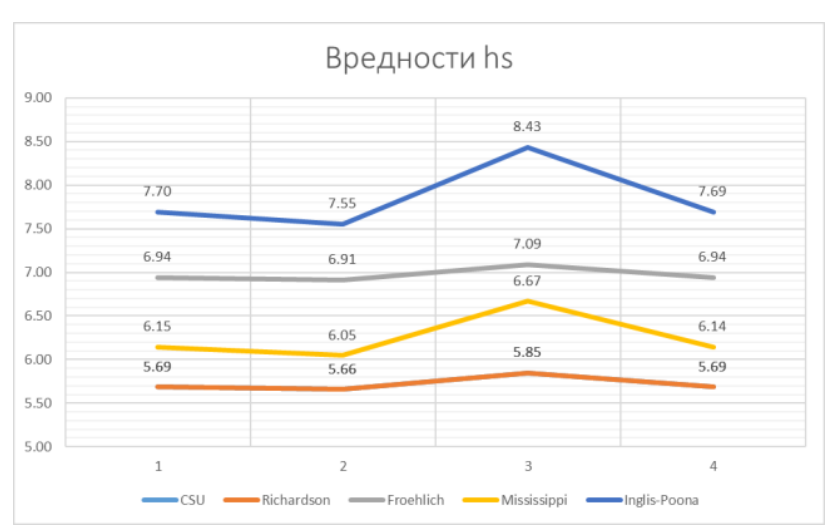

Слика 3. Графички приказ дубине ерозионе јаме применом различитих једначина

\section{5. ЗАШТИТА СТУБОВА У ГЛАВНОМ ТОКУ}

Постоји више начина заштите мостовских стубова од локалне ерозије, најједноставни начин јесте постављањем каменог набачаја око стуба. У новије време се све 
више користи заштита мостовских стубова употребом габиона.

Дно речног корита око мостовског стуба штити се тепихом од крупног камена. По препоруци из рада [1], најједноставнија варијанта је приказана на слици 4.

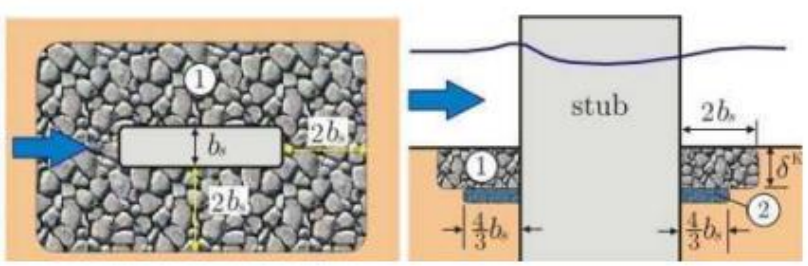

Слика 4. Заштита речног корита око стуба [1].

На основу претходног усвојено је да се испред и иза стубова усвоји заштита у дужини од $2 \cdot 5 \mathrm{~m}=10 \mathrm{~m}$ испред и иза стуба.

Укупна дужина износи $10+12+10=32 \mathrm{~m}$, а ширина износи $10+5+10=25 \mathrm{~m}$.

Из укупне површине треба избацити површину стуба која износи $50.50 \mathrm{~m}^{2}$, тако да укупна површина заштите износи $32 \cdot 25-50.50=749.50 \mathrm{~m}^{2}$.

За прорачун дебљине каменог тепиха користи се познати образац Избаша (Izbash), који се често користи у пројектовању камених тепиха око мостовских стубова [1].

$$
d_{50}=(0.7 / \Delta) \cdot V^{2} /(2 g)=0.15 \mathrm{~m}
$$

Најмања дебљина каменог тепиха је:

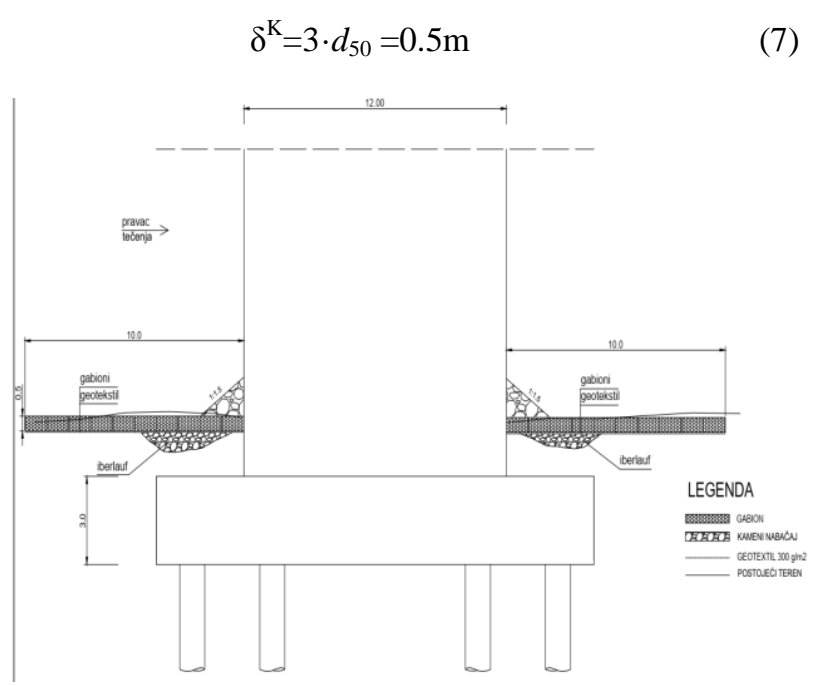

Слика 5. Предлог заштите мостовских стубова

\section{6. ОБАЛОУТВРДЕ}

Обалоутврде припадају типу паралелних регулационих грађевина, чија је главна улога да заштите обалу од ерозије. У најчешћем случају обалоутврде се граде у кривинама водотока, искључиво на конкавној обали водотока.

По потреби обалоутврде се граде на обе обале дуж праволинијске деонице, при регулационим радовима у насељима, пошто поред основне функције заштите обале од ерозије, обалоутврде у овом случају имају и урбанистичку и естетску функцију, такође се изводе и у зони мостова због повећаних брзина.
Укупна ширина конструкције моста ауто пута је 29.40 m. Предвиђено је да обалоутврда буде узводно и низводно по 15 m дужа, што укупно даје конструкцију обалоутврде од $60 \mathrm{~m}$.

\section{1 Типови обалоутврде}

Основна подела обалоутврда је на вертикален и косе. Вертикалне обалоутврде хоризонтална оптерећења преносе на тло. Знатно су скупље него косе обалоутврде и примењују се углавном у специјалним случајевима (луке, пристаништа, марине, канали) или када просторна ограничења не дозвољавају извођење косе обалоутврде.

Косе обалоутврде су искључиво регулационе грађевине, које одликује једноставна конструкција и нижа цена извођења. У ову групу спада велика лепеза објеката, од једноставне заштите обале биљним материјалом до кејског зида са платоом за рекреацију, али сваки има четири основна елемента:

Подлога обалоутврде је посебно изведен слој који се полаже на речно дно са сврхом да прихвати тежину грађевине и друга оптерећења и пренесе их на слабо носиво, муљевито и пешчано тло речног дна. Најчешће се изводи у виду фашинског мадраца или комбинације синтетичких и природних материјала.

Ножица је ослонац целе конструкције и поставља се на подлогу, најчешће је то конструкција од каменог набачаја.

Постељииа има вишеструку улогу, али пре свега представља прелаз између крупног материјала у облози и финог материјала у подлози. Постељица обезбеђује филтрацију, дренирање, заштиту од испирања током паралелним са косином, изравнавање темељног тла (служи као темељ за уградњу облоге), одвајање конструкције од темељног тла, секундарну заштиту у случају губитка дела облоге и дисипацију енергије унутрашњег тока воде.

Облога штити конструкцију од ерозионог дејства воде (струјање, таласи), треба да буде водопропусна и флексибилна (прилагодљива деформацијама). За облогу се користе најразличитији материјали, од биљних материјала (бусен, поплет, фашине) до облога од камена, префабрикованих бетонских елемената, габиона, асфалта и др.

У случају водотока са осцилацијама нивоа до 5-6 m, на обалоутврди се пројектује берма, која доприноси стабилности објекта, а у насељима има и улогу стазе за шетњу. Ширина берме је између 1 и 4 метра.

\section{2 Ножица обалоутврде}

Ножица је ослонац целе конструкције, који се ради од каменог набачаја и габиона. Ножица од камена гради се под водом (директним истоваром камена), осим круне која се гради изнад нивоа радне воде (трајања 2-3 месеца годишње).

Круна се обликује ручно или машински (ролирање косине), ради дефинисања правилног геометријског облика. Димензије ножице се одређују из услова стабилности на клизање и водећи рачуна о максималној дубини ерозије која се очекује по завршетку регулационих радова. 
Прорачун стабилности ножице:

$$
\begin{gathered}
F_{S}=\frac{\left(F \cdot \sin \alpha+G^{\prime}{ }_{N}\right) \cdot f}{F \cdot \cos \alpha} \geq 1.5 \\
F_{S}=\frac{(3.80 \cdot \sin 26.6+17.66) \cdot 0.3}{3.8 \cdot \cos 26.6}=1.71 \geq 1.5
\end{gathered}
$$

где је :

$$
\mathrm{G}^{\prime}{ }_{\mathrm{N}}=\rho^{\prime} \cdot \mathrm{g} \cdot \mathrm{A}_{\mathrm{N}}=0.6 \cdot 9.81 \cdot 3=17.66 \mathrm{KN}
$$

$\mathrm{G}_{\mathrm{N}}{ }^{\prime}$ - тежина ножице под водом $(\mathrm{N}), \mathrm{A}_{\mathrm{N}}$ - површина ножице $\left(\mathrm{m}^{2}\right)$, r' -запреминска маса камена под водом $\left(\mathrm{t} / \mathrm{m}^{3}\right)$

$$
F=G^{\prime} \cdot \sin \alpha-f \cdot G^{\prime} \cos \alpha
$$

$F=21.19 \cdot \sin 26.6-0.3 \cdot 21.19 \cdot \cos 26.6=3.80 \mathrm{KN}$

F - сила којом камена облога делује на ножицу (N), f '- коефицијент трења чврстих материја под водом (f ‘ $=0.30$ за фашински мадрац или геотекстил; $\mathrm{f}^{\text {‘ }}=0.65$ ако је то шљунак)

$$
G^{\prime}=\rho^{\prime} \cdot V \cdot g=0.6 \cdot 3.6 \cdot 9.81=21.19 \mathrm{KN}
$$

$\mathrm{G}^{\prime}$ - сила тежине камене облоге под водом (N), V запремина камене облоге $\left(\mathrm{m}^{3}\right), \rho$ ' - запреминска маса камена под водом $\left(\mathrm{t} / \mathrm{m}^{3}\right)$

$\rho^{\prime}=\left(1+W_{z}\right) \cdot \rho_{k}-\rho=(1+1 \%) \cdot 1.58-1=0.6 t / \mathrm{m}^{3}$

$\rho_{k}=\left(1-n_{k}\right) \cdot \rho_{s}=(1-1 \%) \cdot 1.6=1.58 \mathrm{t} / \mathrm{m}^{3}$

$\mathrm{Wz}$ - влажност засићеног камена, $\rho_{k}$ - запреминска маса камена $\left(\mathrm{t} / \mathrm{m}^{3}\right)$,

$\rho_{s}$ - специфична маса камена $\left(\mathrm{t} / \mathrm{m}^{3}\right), \rho$ - запреминска маса воде $(\mathrm{t} / \mathrm{m} 3), \mathrm{n}_{\mathrm{k}}$ - порозност камена [3].

\section{3 Облога од камена}

Крупноһа камених блокова стабилних на утицај струјања воде одређује се помоћу обрасца Избаша (Isbash, 1936):

$$
d_{50} \geq \frac{1.4}{1.65 \cdot 0.7} \cdot \frac{1.4^{2}}{2 \cdot 9.81} \geq 0.12 \text { усваја се } 0.15 \mathrm{~m}
$$

где су: $\mathrm{d}_{50}$ - пречник каменог блока $50 \%$ заступљености у набачају (m), V - средња профилска брзина $(\mathrm{m} / \mathrm{s}), \eta$ - емпиријски коефицијент који зависи од интензитета турбуленције ( $\eta=0,2$ мала турбуленција; $\eta=0,5$ до 0,7 нормална турбуленција; $\eta=1,4$ велика турбуленција), $\mathrm{g}$ - гравитационо убрзање $\left(\mathrm{m} / \mathrm{s}^{2}\right), \Delta$ - релативна запреминска маса камена, $\mathrm{k}-$ коефицијент који се одређује помоћу израза:

$$
k=\cos 26.6 \cdot\left(1-\frac{t g^{2} 26.6}{t g^{2} 45}\right)
$$

где је: $\theta$ - угао који косина обале заклапа са хоризонталом, $\beta$ - угао унутрашњег трења каменог набачаја $\left(45^{\circ}\right)$ [3].

Облога од каменог набачаја се формира у два слоја, укупне дебљине [2]:

$\mathrm{d}_{\mathrm{KO}}=(1.5$ do 1.8$) \cdot \mathrm{d}_{50}=1.8 \cdot 1.5=0.27 \mathrm{~m}$ усваја се $0.3 \mathrm{~m} \mathrm{(18)}$

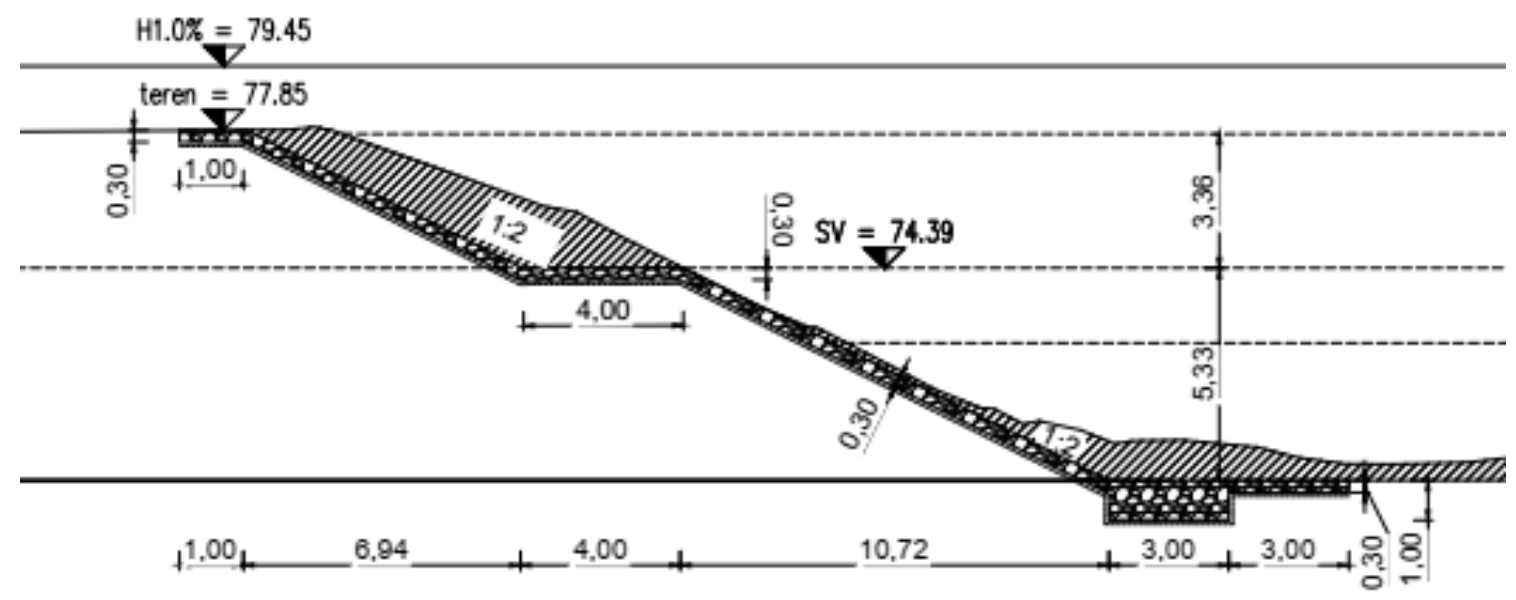

Слика 6. Детаљ леве обалоутврде

\section{7. ЗАКљУЧАК}

У овом раду је приказан прорачун дубине ерозине јаме, где се вредности налазе у рангу између 1-1.5 ширине мостовског стуба, стубове је потребно заштити на описани начин, а након извођења контролисати на сваких 4-5 година као и након проласка великих поплавних таласа.

\section{LITERATURA}

[1] Др Миодраг Јовановић; „Локална ерозија речног корита као главни узрок оштећења мостовских конструкција“, оригинални научни рад.

[2] Др Драгутин Мушкатировић; „Регулација река“, IV издање, Београд 1991.
[3] Др Марина Бабић Младеновић; „Уређење водотока“, Институ за водопривреду Јарослав Черни, Београд 2018.

\section{Kratka biografija:}

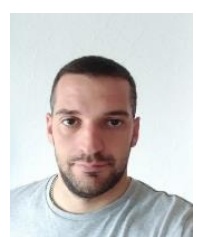

Радован Туцић рођен је у Новом Саду 1992. год. Мастер рад на Факултету техничких наука из области Хидротехничких конструкција одбранио је 2021.год.

контакт: rtucic92@gmail.com 